\title{
Nadciśnienie oporne a zespół obturacyjnego bezdechu sennego
}

\section{Resistant hypertension and obstructive sleep apnea}

\author{
Beata Krasińska', Szczepan Cofta', Angelika Miazga', Ludwina Szczepaniak-Chichef', Tomasz Trafas² \\ Zbigniew Krasiński ${ }^{3}$, Andrzej Tykarski ${ }^{1}$ \\ 'Katedra i Klinika Hipertensjologii, Angiologii i Chorób Wewnętrznych Uniwersytetu Medycznego im. Karola Marcinkowskiego w Poznaniu \\ ${ }^{2}$ Klinika Pulmonologii, Alergologii i Onkologii Pulmonologicznej Uniwersytetu Medycznego im. Karola Marcinkowskiego w Poznaniu \\ ${ }^{3}$ Klinika Chirurgii Ogólnej i Naczyń Uniwersytetu Medycznego im. Karola Marcinkowskiego w Poznaniu
}

\section{Streszczenie}

Obturacyjny bezdech senny (OSA) jest obecnie uważany za jedną z najczęstszych przyczyn nadciśnienia tętniczego opornego. Związek między OSA i nadciśnieniem tętniczym opornym był opisywany w wielu badaniach. W przebiegu OSA nadciśnienie tętnicze stwierdza się u 37-56\% chorych, a wśród pacjentów z nadciśnieniem tętniczym opornym OSA występuje aż u 70-85\%. Do rozwoju nadciśnienia tętniczego opornego u osób z obturacyjnymi zaburzeniami oddychania podczas snu dochodzi prawdopodobnie przez współdziałanie kilku mechanizmów. Kluczową rolę odgrywa hipoksja, która doprowadza do aktywacji układu współczulnego, pobudzenia układu RAA, zwiększonego stresu oksydacyjnego i wzrostu wydzielania endoteliny. Pobudzenie układu RAA i związane z tym podwyższone stężenie angiotensyny II i aldosteronu generuje wzrost oporu naczyniowego, co w konsekwencji zwiększa obciążenie następcze serca. Współistnienie OSA zmniejsza skuteczność terapii hipotensyjnej. W celu uzyskania kontroli ciśnienia tętniczego w tej grupie chorych konieczne jest równoczesne stosowanie kilku leków hipotensyjnych o zróżnicowanym mechanizmie działania, w tym leku moczopędnego.

słowa kluczowe: nadciśnienie tętnicze, nadciśnienie tętnicze oporne, obturacyjny bezdech senny (OSA)

Arterial Hypertens. 2015, vol. 19, no. 2, pages: 95-100

DOI: $10.5603 / A H .2015 .0014$

\section{Summary}

Obstructive sleep apnea (OSA) remains one of the most common causes of resistant arterial hypertension (AH). Association between resistant hypertension and OSA was observed in numerous trials. In patients suffering from OSA resistant AH occurs in 37-56\% of cases, while prevalence of OSA in group of patients suffering from resistant $\mathrm{AH}$ is as much as $70-85 \%$. Presumably pathogenesis of resistant hypertension is determined by coexistence of several mechanisms. The key role in that process plays hypoxia which leads to sympathetic nervous system stimulation, activation of renin-angiotensin system, increase of oxydative stress and endothelin production. Activation of renin-angiotensin system with increase in angiotensin II and aldosterone concentrations leads to rise in peripheral vascular resistance, and in consequence increased afterload. Coexistence of OSA diminishes effectiveness of hypotensive treatment. In order to achieve blood pressure control it is necessary to use simultaneously several antihypertensive agents with different mechanism of action, including a diuretic.

key words: arterial hypertension, resistant hypertension, obstructive sleep apnea (OSA)

Arterial Hypertens. 2015, vol. 19, no. 2, pages: 95-100

DOI: $10.5603 / A H .2015 .0013$

Address for correspondence: dr hab. n. med Beata Krasińska

Katedra i Klinika Hipertensjologii, Angiologii i Chorób Wewnętrznych

Uniwersytetu Medycznego im. Karola Marcinkowskiego w Poznaniu

E-mail: beata.bkrasinska@gmail.com 
Nadciśnienie tętnicze oporne jest to stan, w którym pomimo stosowania 3 leków hipotensyjnych w maksymalnych dawkach (w tym diuretyku), nie udaje się osiągnąć wartości docelowych ciśnienia [1]. Pacjenci z nadciśnieniem opornym to chorzy z grupy dużego i bardzo dużego ryzyka sercowo-naczyniowego, którzy stanowią poważny problem kliniczny i terapeutyczny [2]. Częstość występowania nadciśnienia tętniczego opornego jest trudna do oszacowania, a dane z piśmiennictwa są często rozbieżne. $\mathrm{Z}$ analizy badań de la Sierra z 2011 roku wynika, że nadciśnienie oporne dotyczy 12-13\% osób leczonych hipotensyjnie, natomiast badanie Framingham pokazuje, że wartości docelowe ciśnienia osiąga tylko 49\% pacjentów [3, 4].

Jedną z częstszych przyczyn opornego nadciśnienia tętniczego jest obturacyjny bezdech senny (OSA, obstructive sleep apnea). W przebiegu OSA nadciśnienie tętnicze stwierdza się u 37$-56 \%$ chorych, a wśród pacjentów z nadciśnieniem opornym OSA występuje aż u 70-85\% [5]. Podstawą rozpoznania OSA jest całonocne badanie polisomnograficzne (PSG), które w sposób obiektywny ocenia rodzaj i nasilenie zaburzeń oddychania w czasie snu. Obturacyjny bezdech senny charakteryzuje się powtarzającymi się epizodami zatrzymania lub zmniejszenia przepływu powietrza przez drogi oddechowe na poziomie gardła, przy zachowanym wysiłku oddechowym, co odróżnia bezdech obturacyjny od centralnego. Głównym kryterium diagnostycznym w badaniu polisomnograficznym jest wskaźnik AHI (apnea-hypopnea index) — wskaźnik oceniający liczbę bezdechów i spłyceń oddychania w ciągu godziny, którego wartość powyżej 5 uprawnia do rozpoznania OSA przy istnieniu objawów sugerujących to schorzenie. Jako bezdech określa się przerwę w oddychaniu trwającą co najmniej 10 sekund (sygnał toru oddychania musi wynosić poniżej $10 \%$ referencyjnej amplitudy). Jako spłycenie oddychania określa się redukcję przepływu o co najmniej $30 \%$ z desaturacją wynoszącą co najmniej $4 \%$. Zgodnie z wytycznymi American Academy of Sleep (AASM), podstawą rozpoznania OSA jest stwierdzenie co najmniej 5 epizodów bezdechów i spłyceń oddychania na godzinę w czasie snu $(\mathrm{AHI} \geq 5)[6]$.

Kolejnym warunkiem potwierdzenia rozpoznania jest obecność nadmiernej senności w ciągu dnia trudnej do wytłumaczenia innymi przyczynami bądź 2 spośród 4 objawów: uczucia duszenia lub dławienia w nocy, wybudzeń podczas snu, snu nie dającego wypoczynku oraz upośledzonej zdolności koncentracji Podział OSA opiera się przede wszystkim na wartości AHI — wyróżniamy postać łagodną, gdy wskaźnik ten wynosi od 5 do15, umiarkowaną - od 16-30, a ciężką rozpoznajemy przy $\mathrm{AHI}>30[7,8]$.

Obturacyjny bezdech senny występuje u 9-26\% dorosłej populacji, przy czym 2- lub 3-krotnie częściej u mężczyzn (1 na 4 mężczyzn i 1 na 10 kobiet) Częstość występowania OSA zwiększa się wraz z wiekiem i rozpowszechnieniem otyłości [9].

\section{Patogeneza rozwoju nadciśnienia tętniczego opornego u pacjentów z OSA}

Do rozwoju nadciśnienia opornego w przebiegu zaburzonego oddechu w nocy dochodzi prawdopodobnie przez współdziałanie kilku mechanizmów. Kluczową rolę odgrywa hipoksja, która doprowadza do aktywacji układu współczulnego, pobudzenia układu RAA, zwiększonego stresu oksydacyjnego i wzrostu wydzielania endoteliny (ryc. 1).

\section{Wpływ na układ współczulny}

U znacznej większości pacjentów z bezdechem sennym powierzchnia przekroju tylnej części jamy nosowo-gardłowej jest już wyjściowo mniejsza z racji nagromadzenia tkanki tłuszczowej w obrębie szyi. W czasie snu, z powodu relaksacji mięśni gardła, dochodzi do całkowitego lub częściowego zapadania jego ścian, co prowadzi do bezdechów. Powtarzające się epizody bezdechów z następującymi po nich okresami hipoksemii i hiperkapnii powodują aktywację chemoreceptorów, pobudzenie ośrodka oddechowego i wzrost aktywności układu współczulnego. Aktywacja układu sympatycznego wywołana jest bezpośrednim działaniem czynnika HIF-1 (hypoxia-inducible factor-1), który indukuje stan zapalny w ustroju - zwiększa stężenie CRP, TNF- $\alpha$, interleukiny- 6 , co może prowadzić do rozwoju nadciśnienia tętniczego [10]. Już w 1995 roku Fletcher i wsp. opisali oddziaływanie hipoksji na wartości ciśnienia, wykazując, że ośmiogodzinna hipoksja powoduje zwyżkę ciśnienia tętniczego o $10-15 \mathrm{~mm} \mathrm{Hg}$ utrzymującą się przez przeszło 35 dni [11]. W badaniach wykazano również, że pacjenci z OSA mają szybszą czynność serca i mniejszą częstość oddechów, co wiąże się z ciężkością OSA, niezależnie od obecności nadciśnienia i niewydolności serca [12].

\section{Wpływ na układ RAA}

Jednym z prawdopodobnych mechanizmów wzrostu ciśnienia w przebiegu OSA jest pobudzenie układu RAA i związany z tym podwyższony poziom 


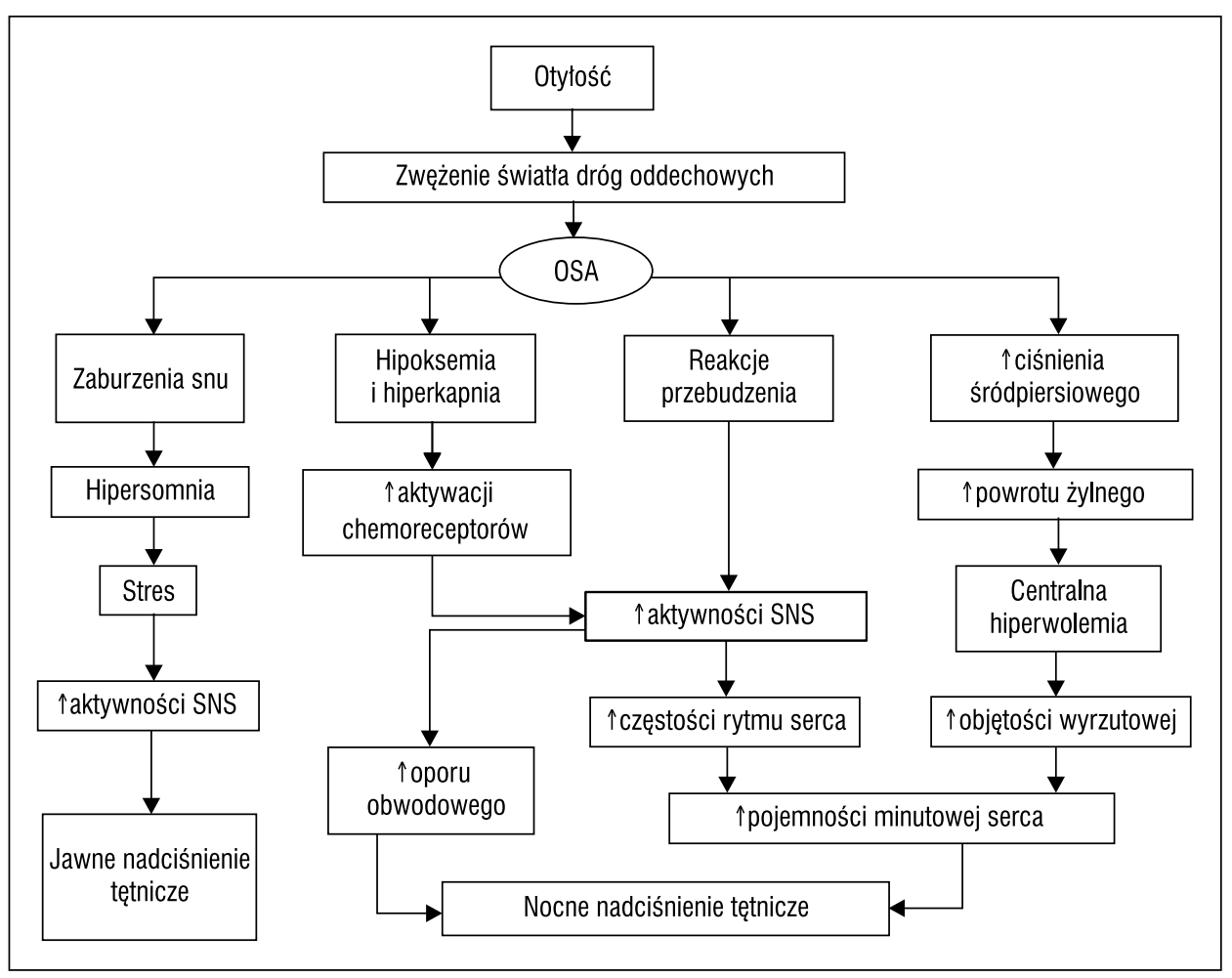

Rycina 1. Patogeneza obturacyjnego bezdechu sennego

angiotensyny II i aldosteronu. Doprowadza to do wzrostu oporu naczyniowego, co w konsekwencji zwiększa obciążenie następcze serca. Duńskie badania wykazały, że zastosowanie leczenia aparatami CPAP u pacjentów z OSA powodowało u spadek ciśnienia tętniczego, który korelował ze zmniejszeniem stężenia reniny i angiotensyny II, a których wyjściowe stężenie było istotnie wyższe $\mathrm{u}$ chorych z OSA niż w grupie kontrolnej [13]. Wpływ angiotensyny II potwierdzają też badania kanadyjskie, w których wykazano, że sześciogodzinna hipoksja wywołana eksperymentalnie powoduje mniejszy o 7,9 $\mathrm{mm} \mathrm{Hg}$ wzrost średniego ciśnienia tętniczego w grupie leczonej losartanem niż w grupie pacjentów przyjmujących placebo [14].

Ostatnio zwrócono uwagę na częstsze występowanie hiperaldosteronizmu u chorych z OSA. Calhoun i wsp. obserwowali zwiększone stężenie aldosteronu w surowicy krwi u prawie co czwartego chorego na OSA, podczas gdy u chorych z pierwotnym nadciśnieniem tętniczym zwiększone stężenie aldosteronu dotyczy niecałych $10 \%$ chorych $[2,15]$. Praca amerykańskich badaczy Gonzaga i Gaddama sugeruje, że to podwyższony poziom aldosteronu może być odpowiedzialny za rozwój NT opornego u pacjentów z OSA, a leczenie spironolaktonem zmniejsza stopień ciężkości OSA u tych pacjentów [16, 17].
Wpływ na funkcję śródbłonka naczyniowego U pacjentów z OSA do niekorzystnych zmian dochodzi również na poziomie śródbłonka. Hipoksja i następowa reperfuzja indukują produkcję wolnych rodników i nadtlenków, co nasila stres oksydacyjny i aktywuje kaskadę stanu zapalnego, która doprowadza do wzrostu stężenia endoteliny i upośledzenia wydzielania tlenku azotu. Stan zapalny zapoczątkowuje proces miażdżycowy $\mathrm{w}$ naczyniach, a także bierze udział we wszystkich dalszych etapach rozwoju procesu miażdżycowego. Wzrost stężenia CRP aktywuje zwiększenie wychwytu LDL do komórek piankowych obecnych w blaszkach miażdżycowych, co może sprzyjać destabilizacji blaszki miażdżycowej [18].

W kilku pracach wykazano podwyższenie stężenia tlenku azotu, a zmniejszenie stężenia CRP, TNF-alfa i cytokin zapalnych po zastosowaniu skutecznej terapii CPAP $[19,20]$. Białko CRP, działając na syntezę NO, powoduje zmniejszenie uwalniania NO i doprowadza do upośledzenia funkcji śródbłonka co prowadzi do wzrostu ciśnienia [21]. Wysokie stężenie CRP zwiększaaktywność endoteliny pierwszej(ET1) peptydu o silnym działaniu wazokonstrykcyjnym [23]. Zaobserwowano również, że spadek ciśnienia tętniczego korelował ze spadkiem stężenia endoteliny oraz redukcją stopnia ciężkości OSA wyrażonej za pomocą AHI. Podwyższone stężenie CRP powoduje pobudzenie receptora AT1, co zwiększa zwrotne 
wchłanianie sodu, uwalnianie aldosteronu i noradrenaliny[22].

Rezultatem hemodynamicznym wymienionych wyżej procesów biochemicznych jest skurcz mięśni gładkich naczyń krwionośnych, wzrost oporu obwodowego i wzrost objętości wewnątrznaczyniowej - co nieuchronnie prowadzi do wzrostu ciśnienia tętniczego Wyniki tych badań wskazują na istotną rolę dysfunkcji śródbłonka naczyniowego na rozwój nadciśnienia tętniczego opornego u pacjentów z OSA.

\section{Nadciśnienie tętnicze oporne a OSA}

Związek między OSA i nadciśnieniem tętniczym opornym był opisywany w wielu badaniach.

Zwiększone ryzyko rozwoju nadciśnienia w grupie chorych z OSA stwierdzono w badaniu Wisconsin Sleep Cohort Study. Z projektu wykluczono pacjentów z istniejącym leczonym bądź nieleczonym nadciśnieniem tętniczym. Określono częstość występowania nowych przypadków nadciśnienia w trakcie 4-8-letniej obserwacji [24]. Po uwzględnieniu wieku, płci, BMI, wyjściowego ciśnienia, znaleziono korelację między częstością występowania nadciśnienia a stopniem ciężkości OSA. Pacjenci z AHI $<5$ mieli prawdopodobieństwo wystąpienia nadciśnienia tętniczego 1,4, podczas gdy u pacjentów z AHI 5-15 zwiększało się ono trzykrotnie $[7,25]$.W tym badaniu wykazano również korelację między stopniem ciężkości zaburzeń oddychania podczas snu a brakiem nocnego spadku skurczowego ciśnienia tętniczego. Przebadano 328 osób, które miały wykonane co najmniej dwukrotnie badanie ABPM oraz badanie polisomnograficzne. Iloraz szans wystąpienia braku spadku nocnego był większy $(4,4)$ u pacjentów z AHI > 15 w porównaniu z pacjentami z grupy z AHI $<5(3,1)$. Nie stwierdzono takiej korelacji dla rozkurczowego ciśnienia tętniczego. Na tej podstawie wysunięto tezę, że nocny brak spadku ciśnienia skurczowego może być mechanizmem, poprzez który OSA przyczynia się do wzrostu ryzyka chorób układu krążenia.

W licznych badaniach wśród chorych z nadciśnieniem tętniczym i współistniejącym OSA obserwowano fazowość związaną z bezdechem (przejściowe zwyżki ciśnienia o $30 \mathrm{~mm} \mathrm{Hg}$ ) i nadciśnienie o typie non-dipper z charakterystycznym brakiem spadku ciśnienia w nocy, przyczyniającym się do wzrostu ryzyka sercowo-naczyniowego $[9,26]$. Największą aktywność współczulną stwierdzano pod koniec epizodu bezdechu, a rejestrowane wówczas wartości ciśnienia tętniczego mogły przekraczać nawet 250/110 mm $\mathrm{Hg}$ — również u osób, u których dzienne pomiary ciśnienia nie dawały podstaw do rozpoznania nadciśnienia tętniczego [27].

Wzajemną zależność OSA i nadciśnienia tętniczego potwierdziło badanie Sleep Heart Health Study (SHHS) przeprowadzone na 6000 osób $\mathrm{z}$ populacji amerykańskiej. Wraz z narastaniem stopnia nasilenia OSA wzrastał procentowy udział osób z nadciśnieniem tętniczym. Wyniki tego badania udowodniły również, że częstość występowania nadciśnienia jest związana z czasem trwania snu. Wykazano, że nadciśnienie tętnicze występowało częściej u osób z krótszym, jak i ze zbyt długim czasem snu, w porównaniu z osobami śpiącymi 7-8 godzin. Obserwowany związek był niezależny od wieku, płci i masy ciała. Badanie to pokazało również silniejszą korelację między OSA u pacjentów tylko z nieznacznie podwyższonym AHI a zwiększoną częstością występowania niewydolności serca i udaru mózgu niż częstością choroby niedokrwiennej serca [28].

Czynniki, które predysponują do wystąpienia OSA u pacjentów z nadciśnieniem tętniczym opornym prezentuje praca autorów brazylijskich. Największą czułość w rozpoznaniu OSA u pacjentów $\mathrm{z}$ nadciśnieniem tętniczym opornym $\mathrm{w}$ tym badaniu miał brak spadku nocnego w zakresie ciśnienia skurczowego (64\%), natomiast dla rozkurczowego czułość ta wynosiła tylko $47 \%$. Duży obwód szyi i cukrzyca miały niską czułość - odpowiednio $33 \%$ i 36\%, ale dużą specyficzność - 84\% i 80\%. $\mathrm{Z}$ kolei dla chrapania i dyslipidemii określono dużą czułość dla rozpoznania OSA $-87 \%$, jednakże małą swoistość- odpowiednio 57 i 30\% [1].

Związek między OSA i nadciśnieniem tętniczym opornym był również obserwowany u pacjentów z przewlekłą niewydolnością nerek. Obecność bezdechu sennego może prowadzić do rozwoju opornego nadciśnienia prawdopodobnie w mechanizmie przewodnienia [29]. Konieczne są dalsze badania, które odpowiedziałyby na pytanie, czy leczenie OSA mogłoby poprawić rokowanie u pacjentów z przewlekłą niewydolnością nerek.

Podsumowując, OSA jest jedną z częstych, odwracalnych przyczyn wzrostu ciśnienia tętniczego i istotnym klinicznie czynnikiem predysponującym do nadciśnienia opornego na leczenie. Nierozpoznany i nieleczony OSA może doprowadzić do rozwoju wtórnego nadciśnienia tętniczego. W związku z tym 7. raport JNC podkreśla konieczność wykluczenia u otyłych chorych OSA jako przyczyny oporności na leczenie hipotensyjne [30]. 


\section{Leczenie OSA}

\section{Oddychanie pod stałym dodatnim ciśnieniem - CPAP}

Podstawową metodą leczenia OSA o nasileniu umiarkowanym oraz ciężkim jest zastosowanie w godzinach nocnych aparatów do ciągłego dodatniego ciśnienia w drogach oddechowych (CPAP, continuous positive airway pressure; w Polsce używa się potocznie nazwy: proteza powietrzna). Znacznie poprawia to komfort życia chorych na OSA, a także powoduje istotne obniżenie ciśnienia tętniczego oraz redukcję częstości występowania epizodów sercowo-naczyniowych o $15 \%$, udarów zaś aż o $20 \%$.

Mimo że ta terapia poprawia czynność śródbłonka i zmniejsza senność w ciągu dnia, to spadek ciśnienia tętniczego jest stosunkowo niewielki. W kilku badaniach wykazano, że ciśnienie skurczowe obniża się tylko od $1,67 \mathrm{~mm} \mathrm{Hg}$ do 3,9/1,4 mm Hg [24]. Największe korzyści uzyskuje się u osób z najcięższą postacią OSA [31]. Wyniki pracy Marin i wsp. wykazały, że pacjenci, którzy odmówili leczenia CPAP lub którzy zostali zdyskwalifikowani, mieli większe ryzyko wystąpienia NT w porównaniu do chorych leczonych CPAP. Hiszpańscy autorzy sugerują, że OSA wydaje się być modyfikowalnym czynnikiem ryzyka nadciśnienia. Autorzy podkreślają fakt, że mimo częstego występowania OSA, jest on rzadko rozpoznawany [32].

\section{Antagoniści aldosteronu}

Terapia nadciśnienia tętniczego $\mathrm{w}$ przebiegu OSA jest trudna i powinna obejmować równoczesne stosowanie kilku leków hipotensyjnych o zróżnicowanym mechanizmie działania, w tym leku moczopędnego, optymalnie - leku hamującego wpływ aldosteronu. Istnieją doniesienia naukowe sugerujące, że leki blokujące receptory dla aldosteronu nie tylko obniżają ciśnienie tętnicze, lecz także zmniejszają liczbę bezdechów w ciagu nocy. W badaniu Gaddama i wsp. dotyczącym grupy 12 chorych z nadciśnieniem tętniczym opornym stwierdzono, że po 8 tygodniach leczenia spironolaktonem doszło do zmniejszenia wskaźnika AHI z 39,8 $\pm 19,5$ na 22,0 $\pm 6,8$ oraz do spadku masy ciała, a także redukcji ciśnienia tętniczego mierzonego w gabinecie (ze $145 / 81 \mathrm{~mm} \mathrm{Hg}$ do $124 / 72 \mathrm{~mm} \mathrm{Hg}$ ), jak również w 24-godzinnej analizie holterowskiej (ze 147/82 $\mathrm{mm} \mathrm{Hg}$ do 130/72 mm Hg).

Wydaje się, że u pacjentów z OSA spironolakton oprócz bezpośredniego działania hipotensyjnego re- dukuje wartości ciśnienia tętniczego również pośrednio - poprzez zmniejszenie obrzęku tylnej ściany gardła i języczka, co redukuje częstość zapadania się górnych dróg oddechowych podczas snu, a więc poprzez zmniejszenie nasilenie OSA [17].

\section{Piśmiennictwo}

1. Drager L.F., Genta P.R., Pedrosa R.P. i wsp. Characteristics and predictors of obstructive sleep apnea in patients with systemic hypertension. Am. J. Cardiol. 2010; 105: 1135-1139.

2. Calhoun D.A., Jones D., Textor S. i wsp. Resistant hypertension: diagnosis, evaluation, and treatment. A scientific statement from the American Heart Association Professional Education Committee of the Council for High Blood Pressure Research. Hypertension 2008; 51: 1403-1419.

3. Shamsuzzaman A.S.M., Gersh B.J., Somers V.K. Obstructive sleep apnea: implications for cardiac and vascular disease. JAMA 2003; 290: 1906-1914.

4. De la Sierra A., Segura J., Banegas J.R. i wsp. Clinical features of 8295 patients with resistant hypertension classified on the basis of ambulatory blood pressure monitoring. Hypertension 2011; 57: 898-902.

5. Lloyd-Jones D.M., Evans J.C., Larson M.G., O’Donnell C.J., Roccella E.J., Levy D. Differential control of systolic and diastolic blood pressure : factors associated with lack of blood pressure control in the community. Hypertension 2000; 36: 594-599.

6. Sleep-related breathing disorders in adults: recommendations for syndrome definition and measurement techniques in clinical research. The Report of an American Academy of Sleep Medicine Task Force. Sleep 1999; 22: 667-689.

7. Young T., Palta M., Dempsey J., Skatrud J., Weber S., Badr S. The occurrence of sleep-disordered breathing among middle-aged adults. N. Engl. J. Med. 1993; 328: 1230-1235.

8. Myśliński W., Dybała A., Mosiewicz J., Prystupa A., Hanzlik J. Cardiovascular abnormalities in patients with obstructive sleep apnoea syndrome. Wiad. Lek. Wars. Pol. 1960 2005; 58: 78-83.

9. Young T., Peppard P.E., Gottlieb D.J. Epidemiology of obstructive sleep apnea: a population health perspective. Am. J. Respir. Crit. Care Med. 2002; 165: 1217-1239.

10. Eltzschig H.K., Carmeliet P. Hypoxia and inflammation. N. Engl. J. Med. 2011; 364: 656-665.

11. Fletcher E.C., Bao G., Miller C.C. Effect of recurrent episodic hypocapnic, eucapnic, and hypercapnic hypoxia on systemic blood pressure. J. Appl. Physiol. Bethesda Md 1985 1995; 78: 1516-1521.

12. Narkiewicz K., Montano N., Cogliati C., van de Borne P.J., Dyken M.E., Somers V.K. Altered cardiovascular variability in obstructive sleep apnea. Circulation 1998; 98: 1071-1077.

13. Møller D.S., Lind P., Strunge B., Pedersen E.B. Abnormal vasoactive hormones and 24-hour blood pressure in obstructive sleep apnea. Am. J. Hypertens. 2003; 16: 274-280.

14. Foster G.E., Hanly P.J., Ahmed S.B., Beaudin A.E., Pialoux V., Poulin M.J. Intermittent hypoxia increases arterial blood pressure in humans through a Renin-Angiotensin system-dependent mechanism. Hypertension 2010; 56: 369-377.

15. Pedrosa R.P., Drager L.F., Gonzaga C.C. i wsp. Obstructive sleep apnea: the most common secondary cause of hypertension associated with resistant hypertension. Hypertension 2011; 58: 811-817.

16. Gonzaga C.C., Gaddam K.K., Ahmed M.I. i wsp. Severity of obstructive sleep apnea is related to aldosterone status in subjects with resistant hypertension. J. Clin. Sleep Med. JCSM Off Publ. Am. Acad. Sleep Med. 2010; 6: 363-368.

17. Gaddam K., Pimenta E., Thomas S.J. i wsp. Spironolactone reduces severity of obstructive sleep apnoea in patients with resistant hypertension: a preliminary report. J. Hum. Hypertens. 2010; 24: 532-537.

18. Zhang R., Zhang Y.Y., Huang X.R. i wsp. C-reactive protein promotes cardiac fibrosis and inflammation in angiotensin II-induced hypertensive cardiac disease. Hypertension 2010; 55: 953-960. 
19. Kato M., Roberts-Thomson P., Phillips B.G. i wsp. Impairment of endothelium-dependent vasodilation of resistance vessels in patients with obstructive sleep apnea. Circulation 2000; 102: 2607-2610.

20. Imadojemu V.A., Gleeson K., Quraishi S.A., Kunselman A.R., Sinoway L.I., Leuenberger U.A. Impaired vasodilator responses in obstructive sleep apnea are improved with continuous positive airway pressure therapy. Am. J. Respir. Crit. Care Med. 2002; 165: 950-953.

21. Venugopal S.K., Devaraj S., Yuhanna I., Shaul P., Jialal I. Demonstration that C-reactive protein decreases eNOS expression and bioactivity in human aortic endothelial cells. Circulation 2002; 106: 1439-1441.

22. Vongpatanasin W., Thomas G.D., Schwartz R. i wsp. C-reactive protein causes downregulation of vascular angiotensin subtype 2 receptors and systolic hypertension in mice. Circulation 2007; 115: 1020-1028.

23. Virdis A., Ghiadoni L., Plantinga Y., Taddei S., Salvetti A. C-reactive protein and hypertension: is there a causal relationship? Curr. Pharm. Des. 2007; 13: 1693-1698.

24. Barbé F., Durán-Cantolla J., Sánchez-de-la-Torre M. i wsp. Effect of continuous positive airway pressure on the incidence of hypertension and cardiovascular events in nonsleepy patients with obstructive sleep apnea: a randomized controlled trial. JAMA 2012; 307: 2161-2168.
25. Young T., Peppard P., Palta M. i wsp. Population-based study of sleep-disordered breathing as a risk factor for hypertension. Arch. Intern. Med. 1997; 157: 1746-1752.

26. Hla K.M., Young T., Finn L., Peppard P.E., Szklo-Coxe M., Stubbs M. Longitudinal association of sleep-disordered breathing and non-dipping of nocturnal blood pressure in the Wisconsin Sleep Cohort Study. Sleep 2008; 31: 795-800.

27. Wolf J. Otyłość a bezdech senny. Kardiologia Na Co Dzień 2007; 3: 113-119.

28. Gottlieb D.J., Redline S., Nieto F.J. i wsp. Association of usual sleep duration with hypertension: the Sleep Heart Health Study. Sleep 2006; 29: 1009-1014.

29. Abdel-Kader K., Dohar S., Shah N. i wsp. Resistant hypertension and obstructive sleep apnea in the setting of kidney disease. J. Hypertens. 2012; 30: 960-966.

30. Chobanian A.V., Bakris G.L., Black H.R. i wsp. Seventh report of the Joint National Committee on Prevention, Detection, Evaluation, and Treatment of High Blood Pressure. Hypertension 2003; 42: 1206-1252.

31. Barbé F., Durán-Cantolla J., Capote F. i wsp. Long-term effect of continuous positive airway pressure in hypertensive patients with sleep apnea. Am. J. Respir. Crit. Care Med. 2010; 181: 718-726.

32. Marin J.M., Agusti A., Villar I. i wsp. Association between treated and untreated obstructive sleep apnea and risk of hypertension. JAMA 2012; 307: 2169-7216. 